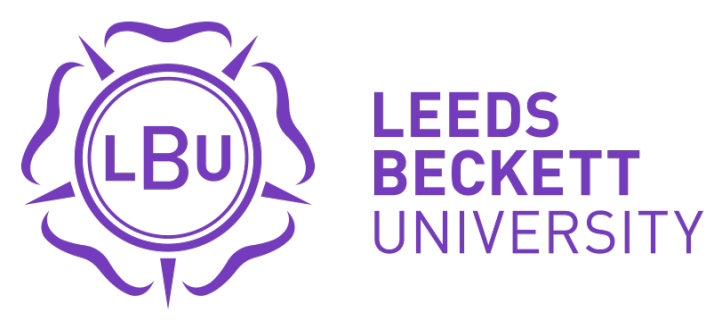

Citation:

Jankowski, G (2016) Who stops the sweatshops? Our neglect of the injustice of maldistribution. Social and Personality Psychology Compass, 10 (11). pp. 581-590. ISSN 1751-9004 DOI: https://doi.org/10.1111/spc3.12272

Link to Leeds Beckett Repository record:

https://eprints.leedsbeckett.ac.uk/id/eprint/3001/

Document Version:

Article (Accepted Version)

The aim of the Leeds Beckett Repository is to provide open access to our research, as required by funder policies and permitted by publishers and copyright law.

The Leeds Beckett repository holds a wide range of publications, each of which has been checked for copyright and the relevant embargo period has been applied by the Research Services team.

We operate on a standard take-down policy. If you are the author or publisher of an output and you would like it removed from the repository, please contact us and we will investigate on a case-by-case basis.

Each thesis in the repository has been cleared where necessary by the author for third party copyright. If you would like a thesis to be removed from the repository or believe there is an issue with copyright, please contact us on openaccess@leedsbeckett.ac.uk and we will investigate on a case-by-case basis. 
Running Head: WHO STOPS THE SWEATSHOPS?

Who stops the sweatshops? Our neglect of the injustice of maldistribution

Glen S. Jankowski

School of Social Sciences, Leeds Beckett University, Leeds, LS1 3HE, UK. Email: g.jankowski@leedsbeckett.ac.uk

NOTE: This is a pre-publication version of the following article: Jankowski, G. S., (in press).

Who stops the sweatshops? Our neglect of the injustice of maldistribution, Social and Personality Psychology Compass. 
Running Head: WHO STOPS THE SWEATSHOPS?

\begin{abstract}
Researchers have attempted to hold fashion, beauty and toy industries' promotion of narrow beauty ideals responsible for the injustice of body dissatisfaction. We advocate for reform by calling upon the industries to represent plus-sized and older models (e.g., on catwalks) as antidotes to narrow beauty ideals; citing evidence that the use of such models are no less profitable. This attempts to address what Fraser (1995) calls the injustice of misrecognition. This advocacy however not only masks another injustice these industries perpetuate: maldistribution (Fraser, 1995), but it can actively worsen it. This is most poignantly exemplified by the 250 million sweatshop workers in the Global South working in these industries. Those of us advocating against these industries' injustices, are encouraged to join People and Planet in their campaign to use universities' vast purchasing power for sweatshop reform. This is one small way to advocate against maldistribution, redressing the imbalance.
\end{abstract}

Keywords: body dissatisfaction; sweatshops; injustice 
Running Head: WHO STOPS THE SWEATSHOPS?

\section{Who stops the sweatshops? Our neglect of the injustice of maldistribution}

Psychology has been criticized extensively for its individualizing focus; for colluding with neoliberalism through placing the responsibility of sociocultural problems onto individuals (King, 1963; Parker \& Spears, 1996). Notably, Martin Luther King Jr. addressed the American Psychiatric Association in 1963:

"There is a word in modern psychology which is now probably more familiar than any other word in psychology. It is the word: maladjusted... [But] there are some things in our social system that I'm proud to be maladjusted to...I never intend to adjust myself to the viciousness of lynch mobs; I never intend to become adjusted to the evils of segregation and discrimination; I never intend to become adjusted to the tragic inequalities of the economic system which will take necessity from the masses to give luxury to the classes.... The salvation of our world lies in the hands of the maladjusted".

Fifty-three years on, one area of psychology is booming. My field has its own eponymous journal, various research clusters such as the Centre for Appearance Research in Bristol, UK and over 10,000 peer reviewed publications listed in PsychInfo. It is the field of body dissatisfaction (or appearance shame) research. We, researchers in the field, have branched into two groups. The first group's approach tends to locate the causes of body dissatisfaction within the individual. Namely, that it is primarily an individual's faulty hormones, thoughts or behaviours that have led to their body dissatisfaction and that therefore can be reduced through individual level intervention (e.g., CBT or anti-depressants; Cash, 2011; Etcoff, 2002; Pruzinsky, 2004).

The second group's approach rejects the idea that body dissatisfaction is caused by the individual and can be loosely described as sociocultural body dissatisfaction researchers (e.g., Chrisler, Fung, Lopez, \& Gorman, 2013; Jankowski, Fawkner, Slater, \& Tiggemann, 2014; Swami \& Szmigielska, 2013; Tiggemann \& Polivy, 2010; Yager, Diedrichs, Ricciardelli, \& Halliwell, 2013 etc.). Our work documents appearance pressures emanating from various industries (e.g., via content analyses of fashions magazines, surveys on the impact of beauty ideals etc; Diedrichs \& Lee, 2010; Jankowski et al., 2014). 
Running Head: WHO STOPS THE SWEATSHOPS?

By shifting the focus from the individual onto the 'sociocultural, arguably then this second approach produce the more progressive research. Indeed the sociocultural body dissatisfaction approach is underpinned by a justice framework. We describe body dissatisfaction as "an injustice" (Rhode, 2009, p. 1033) as "suffering" (Pruzinsky, 2004, p. 71) and "distress" (Avalos, Tylka, \& Wood-Barcalow, 2005, p. 286). Appearance pressures specific to body fat (i.e., weightism) have been described as "appearance stereotyping and discrimination" (Lavin \& Cash, 2001, p. 51) a "form of prejudice” (Maine, 2013, p. 25) and "as a social justice issue" (Steiner-Adair et al., 2002, p. 403). Researchers have also made parallels between body dissatisfaction and other forms of injustice. For example, Macgregor (1979; as cited in Rumsey \& Harcourt, 2004, p. 83) argues that " a visible difference comprises a 'social disability" and Margaret Maine argues weightism is "potentially more powerful and pervasive than racism, sexism or ageism" (Maine, 2013, p. 26).

\section{What is an injustice?}

Given that injustices is not defined in the sociocultural body dissatisfaction approach, it is important to consider what injustices are. Nancy Fraser's (1995) Status Model of Justice does so. Fraser sees justice as people having the ability to fully participate in society and injustices arising when this ability to participate is withheld. This withholding can occur either because of misrecognition, "[the] institutionalized patterns of cultural value [that] constitute some actors as inferior, excluded, wholly other or simply invisible, hence as less than full partners in social interaction" (Fraser, 2001, p. 24), or maldistribution, where "economic structures, property regimes or labour markets deprive actors of the resources needed for full participation" (Fraser, 2001, p. 27).

Fraser $(1995 ; 1998)$ asserts that justice cannot be achieved when either misrecognition or maldistribution are advocated for separately. To demonstrate, Fraser provides the example of a campaign to give single mothers higher welfare benefits. She notes whilst this campaign 
Running Head: WHO STOPS THE SWEATSHOPS?

may help to undo maldistribution (i.e., the ability of single mothers to afford food), it fails to attend to misrecognition (i.e., the cultural stigma directed at 'welfare mothers'). Likewise advocacy to destigmatize sex work fails to tackle the poverty (i.e., maldistribution) that drives many into sex work in the first place. Instead, maldistribution and misrecognition must be combatted together.

Under Fraser's (1995) Status Model of Justice then, the sociocultural body dissatisfaction approach states that people experience the injustice of misrecognition manifesting in body dissatisfaction, disordered eating and other health impacts. Misrecognition is caused by unrealistic appearance representations that the fashion, fitness and beauty industries promote via mass media. The sociocultural body dissatisfaction approach seeks to undo this misrecognition by advocating for greater and more diverse representations.

This paper focuses on what is missing from the sociocultural approach to body dissatisfaction and highlights some of the problematic assumptions of this work. Specifically, I argue that the sociocultural body dissatisfaction approach, whilst ostensibly progressive, not only ignores another injustice these injustices produces- that of maldistribution - but can actively worsen it. I shall demonstrate this neglect by examining three assumptions this approach makes about the injustices produced by the fashion, fitness and beauty industries. The first assumption is that these industries' only injustice is misrecognition. Specifically, these industries are solely criticized for representing people in unrealistic ways, resulting in body dissatisfaction and associated health outcomes. The second assumption is that these industries' injustices only affect people in the Global North. Others are overlooked. Finally, the third assumption is that these industries injustices can be combatted without any loss of profit. Indeed, industries are told if they represent people in more realistic ways they can increase their profits. In this next section each assumption is described and illustrated. 


\section{Assumption 1) The only injustice these industries produce is misrecognition}

The first assumption, that these industries only injustice is misrecognition or that misrecognition is their most pressing injustice, can be seem in a study by Chrisler and colleagues (2013) published in Body Image. The authors analysed tweets to the 2014 Victoria's Secret Fashion Show. They found that many twitter users reported body dissatisfaction after viewing the fashion show. The researchers recommended that people sent their own 'body positive' tweets the next time the show aired in order to counter this injustice.

American plus-size model Tess Holliday also makes this assumption. In May 2015, Holliday criticized various fashion companies for having inconsistent clothing sizes. In her Instagram post, she included an image of different clothing labels with differing sizes to demonstrate (Figure 1). She captioned the image: "At the end of the day, it's how you feel that matters, not the label in your clothes" (Stern, 2015, para. 7).

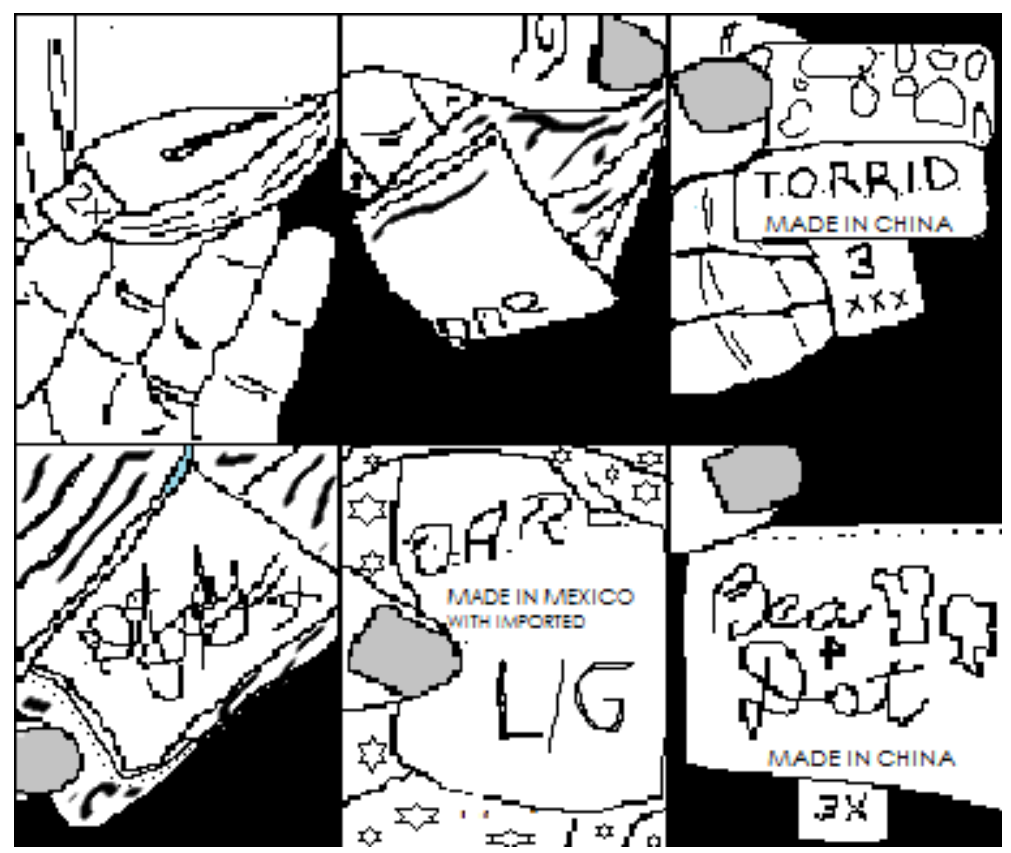

Figure 1. Tess Holliday's Instagram post showing various clothing labels with varying sizes

At the time of writing, Holliday's post has gone viral, amassing over 20,000 Instagram likes and has received widespread media coverage. For example, a Huffington Post 
article covered Holliday's post. It was titled “Plus Size Model Tess Holliday Shows Why You Shouldn't Worry About Your Clothes Label"' (see Figure 2).



Figure 2. Media coverage of above Tess Holliday's Instagram post

However, misrecognition is not the only injustice these industries produce. As Fraser (1995) conceptualizes, they produce the injustice of maldistribution too. This is exemplified by the operation of sweatshops by these industries (ds3375, 2014; Monella, 2012; Ye, 2013). NGO and governmental investigations, such as those by the US Department of Labor, The National Labour Committee, Workers Rights Consortium, Global Labour Rights and Students and Scholars Against Corporate Misbehaviour have long documented how. These largely US and China based organizations have interviewed workers or gone 'undercover' into the factories, in order to highlight the worker's conditions. Minimal pay, forced overtime and poor health and safety investment are just some of the better known sweatshop conditions companies such as Mattell, Disney and Victoria's Secret employ (China Labour Watch, 2015; ds3375, 2014; Ye, 2013). Among the lesser known sweatshop conditions is the suppression of worker's basic right to organize, form a union and indeed, strike. For example, the fashion company identified in Chrisler's Twitter study, Victoria's Secret, sell bikinis made by 
Running Head: WHO STOPS THE SWEATSHOPS?

Bangladeshian and Sri Lankan women in Jordan sweatshops (ds3375, 2014, p. 33; Tasini, 2007). The women are reported to work up to 15 hours a day, receiving only 1 day off every 3 months. They are banned from unionizing and are expected to sew one bikini every three minutes. Once shipped to the US, each bikini sells for around 14 dollars and yet the workers who make them are paid just 4 cents for each one.

In Holliday's Instagram post (see Figure 1) two of the clothe labels pictured, D.A.R.E and Torrid, reveal that they were made in Mexico and China. The use of sweatshops is reportedly commonplace in both countries (Daly, 2014; Monella, 2012). For example, The National Commission of Human Rights has found that 1.5 million children aged between 5 and 17 years are illegally employed in Mexican sweatshops (Daly, 2014; Monella, 2012). Investigations by the Worker Rights Consortium in two Mexican factories reported that workers earned less than the minimum legal wage and were stopped from joining unions by supervisors in some cases by physical and sexual intimidation (Van Ham, n.d.; Worker rights consortium, 2013). Similarly, War on Want estimate that 482 million Chinese are on less than \$2 a day working in sweatshops (Daly, 2014).

Holliday finished her Instagram post recommending her favourite clothing companies, one of which was ASOS. ASOS are also reported to distribute clothes made in sweatshops. Furthermore, investigations by multiple unions and VICE News have found that ASOS' UK distribution factory is akin to a sweatshop. The Eastern European and British workers are reported to earn just $£ 6.77$ an hour, are bullied by management and regularly work up to 100 hours a week (Clifton, 2015).

Misrecognition is also assumed to be the beauty and toy industries' only injustice. Like the fashion industry sweatshops are commonplace. For example, Disney have been widely criticized for their unrealistic depiction of people in their films (A Mighty Girl, 2013). Little is said about Disney's sweatshops workers who are reported to also be minimally paid, 
Running Head: WHO STOPS THE SWEATSHOPS?

forced to work overtime and even banned from speaking to each other (Mattera, 2015; Ye, 2013). Indeed, according to the National Labour Committee, per hour Disney pay workers the equivalent of 21p in China, 18p in Haiti and 3p in Bangladesh (Chamberlain, 2011; Mattera, 2015; Ye, 2013). Sweatshops also produce our toys, electronics (e.g., laptops and mobile phones) and cosmetics (China Labour Watch, 2012, 2014). Under capitalism sweatshops are endemic.

It is easy to underestimate the prevalence of sweatshops because of industries' whitewashing. For example, factory supervisors regularly coach sweatshop workers on what to say to inspectors and company boards direct millions to disguise their sweatshop practices through expensive PR companies (China Labour Watch, 2012; Hoskins, 2014). We also must not mistake occasional heavy media coverage or international outrage for sweatshops closures. So far, at least, outrage has not equated to reform. Demonstrably, the 2013 Rana Plaza factory collapse that killed over 1,133 Bangladeshi workers garnered widespread media coverage (International Labour Office, 2015; Parveen, 2014). The International Labour Rights Report (2015, p. 9) describes the collapse as "put[ting] the question of the sustainability of supply chains at the top of the international agenda", for instance. Nonetheless, after the collapse, companies like Adidas, Nike and Benneton still owe survivors $£ 6$ million in compensation and other similar sweatshop factories remain in operation, some also on the brink of collapse (Parveen, 2014).

The assumption that misrecognition is these industries only injustice ignores the other injustice they cause: maldistribution. Specifically, Holliday's post and related media coverage encourages consumers not to worry about labels and by proxy their sweatshop origins. This is in spite of campaigns that explicitly encourage consumers to upload photos of their clothing labels on social media in order to shame companies' use of sweatshops (The Fashion Mob, 2013). Similarly, if advocates went with Chrisler and colleagues' (Chrisler et al., 2013) 
Running Head: WHO STOPS THE SWEATSHOPS?

recommendations, the trending criticism on twitter of Victoria's Secret would be about their representation of too-thin models. Not their use of sweatshop factories in Jordan (ds3375, 2014; Tasini, 2007).

\section{Assumption 2) Only people in the Global North are affected by these industries' injustices}

The second assumption is that these industries' injustices only affect people in the Global North. For example, one article in The Conversation, an online news blog, is titled: "What Role Does the Fashion Industry Play in Women's Health and Self Image?” (Koskie, 2015). Another in $i-D$, an online blog, carries the headline: "How does the fashion industry affect the bodies of young women" (Mair, 2014).

This assumption is also made in sociocultural body dissatisfaction studies. For example, researchers have focussed on highlighting the injustice of the fashion and beauty industries by assessing select groups of industries' workers body dissatisfaction. Specifically, in a series of survey studies, researchers have assessed fashion models (Santonastaso, Mondini, \& Favaro, 2002; Swami \& Szmigielska, 2013), fashion students (Petersons, Phillips, \& Steinhaus, 1996) and beauty industry employees (Lukács-Márton, Vásárhelyi, \& Szabó, 2008), arguing that they face more injustice because by definition their occupations bring them most proximate to the industries.

According to these articles and studies, it is only Global Northern people's health and bodies that count as being affected by these industries' injustices. Ignored are the estimated 250 million who work in sweatshops, most of whom are from the Global South. Specifically, $61 \%$ of sweatshops are estimated to be in Asia, 32\% in Africa, and 7\% in Latin America (Anti-Sweatshop League, n.d.; Daly, 2014; Do Something, n.d.). Women make up the majority, comprising between $80 \%$ and $95 \%$ of workers (Daly, 2014; Do Something, n.d.). So in Chrisler and colleagues' Twitter study only Global Northern people are assumed to be suffering in comparison' to Victoria's Secret. But how do the Victoria Secret Sri Lankan and 
Running Head: WHO STOPS THE SWEATSHOPS?

Bangladishian sweatshop workers compare? In the survey studies (Lukács-Márton et al., 2008; Petersons et al., 1996; Santonastaso et al., 2002; Swami \& Szmigielska, 2013) it is only those who study fashion at a US university, who model the fashion garments or who work in the beauty industries that count as workers affected by these industries' injustices. The largest group of workers in these industries, those most affected, the sweatshop workers, are ignored.

\section{Assumption 3) That misrecognition can be undone without loss of profits}

The third assumption this approach makes is that these industries' injustices can be combatted not only without any loss of profits but the gain of profits. Indeed, there exists a body of sociocultural body dissatisfaction research that has offered recommendations for industries to sell even more products. For example, in 2010 Diedrichs and Lee explored the body dissatisfaction of Australian men who viewed adverts that featured average-sized models against men who viewed adverts that featured muscular male models. They also measured advertising effectiveness by asking the men how likely they would be to buy various beauty products. From their results, the body dissatisfaction researchers concluded that the beauty and fashion industries should use average-sized models in their adverts not only because these latter adverts did not make men feel body dissatisfied but also because these adverts were rated as effective as adverts with muscular models. Thus Diedrichs and colleagues implied that consumers would be even more likely to buy the products. A similar study with female fashion models made the same recommendations to industry the following year (Diedrichs \& Lee, 2011).

Whether implicit or explicit, this above work legitimizes these industries by helping them become more profitable and powerful. Some researchers are explicit in their legitimization, addressing companies specifically in their work. Specifically Lewis and colleagues (2011) conducted a content analysis of images of women in US fashion 
Running Head: WHO STOPS THE SWEATSHOPS?

magazines. They assert that White wealthy women have "high spending power" (pg. 101) and have "vast potential as a market" (pg. 108) and on this basis should be recognized by the fashion industry through their magazines images and on their catwalks. Further, the researchers describe these industries as harmless, as benignly "cater[ing] to needs and desires" (pg. 106). They are merely asked to "facilitate" and "make room for" older women (pg. 108). Such euphemistic language belies the reality of these industries. Capitalism requires that these industries put creating profits above any other goal. By their very nature these industries do not cater for needs then, they create them, regardless of any harm caused to individuals or society (Fraser, 2001).

This follows body dissatisfaction researcher's defence of these industries more generally. For instance, Harvard professor Nancy Etcoff is author of Survival of the Prettiest: The Science of Beauty (Etcoff, 2002). According to the blurb on the back, the book:

"demonstrates how beauty is not a cultural construct that exists to tyrannize women [and] line the pockets of fashion designers, but a universal fascination with the human form which developed along Darwinian lines since the dawn of man".

The assumption that these industries can undo their injustices without any loss of profits is flawed because maldistribution fundamentally occurs because of the profit imperative. Industries wish to save as much money as possible. Therefore they pay their workers little, they invest minimally in health and safety, force overtime and repress union work (Holt, 2014). This is to keep workers cheap. Though never as much as industries claim nor more than industries can afford (e.g., Pollin, Burns, \& Heintz (2004) found that doubling sweatshop workers' wages would increase the consumer cost of an item by just $1.8 \%$ on average); industry reform, combatting maldistribution, must come at the expense of some profits on the industries' part.

\section{A dose of perspective: Working in a sweatshop is worse than having body dissatisfaction}


Running Head: WHO STOPS THE SWEATSHOPS?

Some perspective is needed when considering our sociocultural body dissatisfaction work.

There are many, often successful, attempts to combat misrecognition. For example,

responding to an online Change.org petition which gained over 34,000 signatures calling for the recognition of girls with alopecia, Mattel created and sold a line of bald Barbies in 2012 (Bingham, 2012). Likewise, Disney successfully reversed its sexualized redesign of their Brave character Merrida after another petition garnered over 260,000 signatures (Rakoska, 2015).

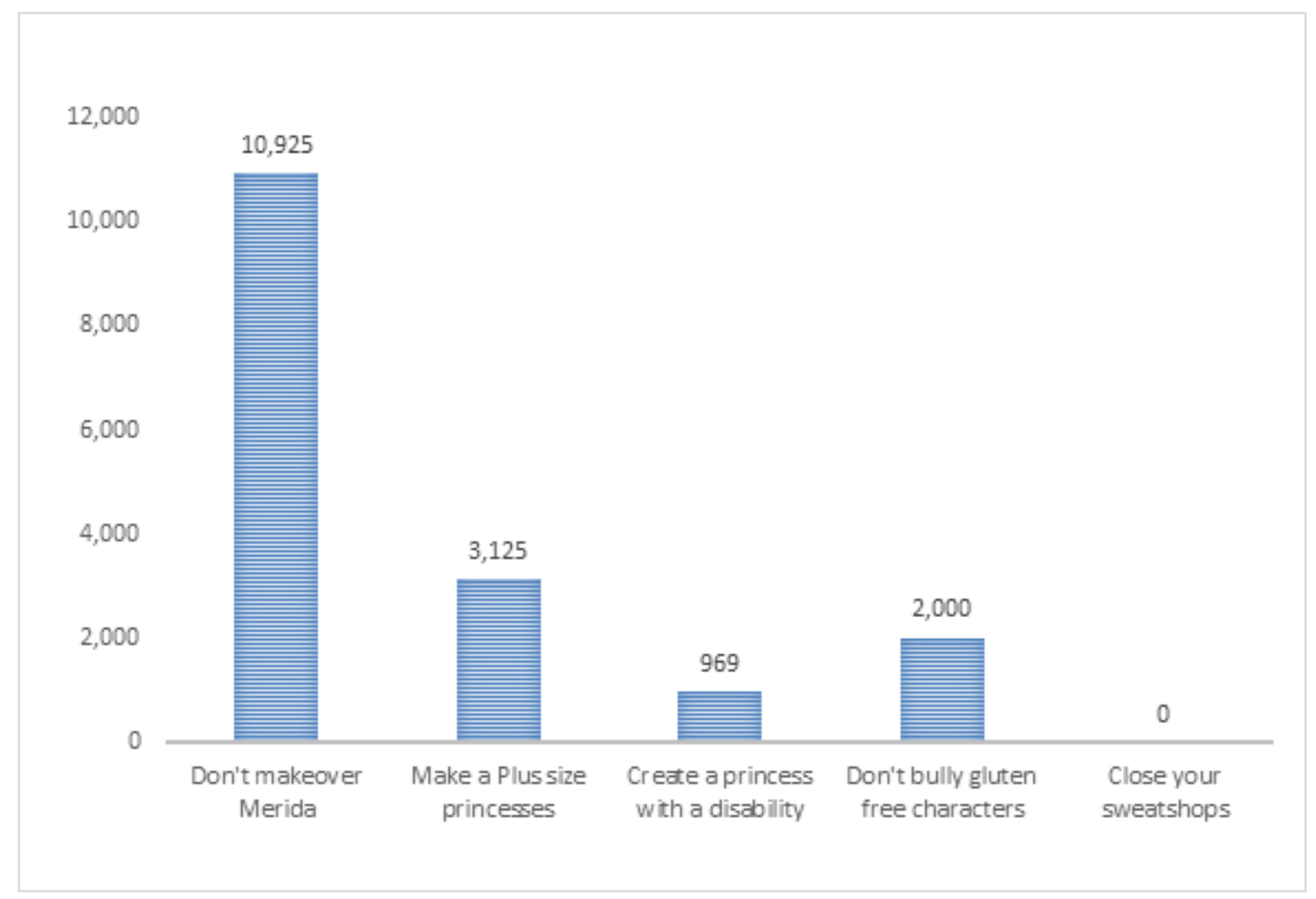

Figure 3. Average number of signatures per month on Change.org petitions to Disney in July 2015

In contrast, calls against maldistribution are fewer and have rarely been successful. For example, there are very few petitions against sweatshop abuses on Change.org in general and none to Disney (see Graph 1). One exception was created by China Labour Watch (China Labour Watch, 2015). This petition arose from the organization's own investigations into Disney and Mattell toy factories in China between June and November 2014. China Labour Watch addressed the companies selling the toys to address the sweatshop conditions. To date 
Running Head: WHO STOPS THE SWEATSHOPS?

the petition has gained a little over 1,000 signatures. The only company to respond to the petition, Mattel, have denied all allegations of abuse, refusing even to allow China Labour Watch to make their response letter public. Another rare petition against sweatshops was created in 2013 by the The Fashion Mob to pressure fashion industries to invest $1 \%$ of their profits in sweatshop reform (The Fashion Mob, 2013). Again, this petition has also had similar limited success gaining only 729 signatures and is currently closed.

Maldistribution is an urgent issue. In Fraser's own words, it is "occurring despite—or because of - an acceleration of economic globalization, at a time when an aggressively expanding capitalism is radically exacerbating economic inequality" (Fraser, 2001, p. 4). Globalization and the increasing power that these industries are quietly gaining has meant that maldistribution including sweatshops are growing (Hoskins, 2014). The Trans-Atlantic Trade Agreement, where companies can sue governments if perceived to be infringing on their right to make profits, provides one example of this. This has opened the gateway for companies like the cigarette manufacturer Phillip Morris to successfully intimidate state governments who are held up as infringing on a company's right to make profits (i.e., by attempting to implement anti-smoking campaigns; Monbiot, 2013).

Sociocultural body dissatisfaction researchers can take action. Indeed, we are well positioned to advocate against these industries' maldistribution for two reasons. First, because, as outlined above, much of our work is already concerned with these industries' activities and how they harm people. Secondly, because like other academics, sociocultural body dissatisfaction researchers are usually part of universities and public organizations that purchase large amounts of produce from these and similar industries (e.g., garments, electronics). As large buyers of these products, universities have considerable negotiating power in the conditions in which these products are made in. For example, in the UK, universities are estimated to spend $£ 10$ billion each year on computers, laptops, printers and 
Running Head: WHO STOPS THE SWEATSHOPS?

other electronics, also made in sweatshops (Willgress, 2014). People and Planet have therefore been campaigning to affiliate universities to Electronics Watch and the Workers' Rights Consortium (Willgress, 2014). These are two independent organizations working on the ground in the factories, speaking to workers away from the supervisors and factories to properly assess sweatshop conditions (People and Planet, 2015). They use the university's vast buying power to push, alongside workers in the factories, for better conditions. We can join them.

\section{Conclusion}

Sociocultural body dissatisfaction researchers advocate against the fashion, toy and beauty industries to represent people better in order to undo body dissatisfaction. This tackles the injustice of misrecognition. Not only does this advocacy ignore the injustice of maldistribution, but when these industries are legitimized, as this work often does, maldistribution is actively worsened. This oversight is most poignantly evidenced by the continual existence and indeed, increase, of sweatshops in the Global South. Instead advocacy that combats maldistribution is needed. Joining the campaign for universities to affiliate to sweatshop monitoring organizations and improve conditions provides one way of doing so, retipping the balance. 
Running Head: WHO STOPS THE SWEATSHOPS?

\section{References}

A Mighty Girl. (2013). Disney: Say no to the Merida makeover, keep our hero brave! Retrieved July 1, 2015, from https://www.change.org/p/disney-say-no-to-the-meridamakeover-keep-our-hero-brave

Anti-Sweatshop League. (n.d.). Maps and statistics. Retrieved January 13, 2016, from https://sites.google.com/site/antisweatshopleague/maps-and-statistics

Avalos, L., Tylka, T. L., \& Wood-Barcalow, N. (2005). The Body Appreciation Scale:

Development and psychometric evaluation. Body Image, 2(3), 285-297. http://doi.org/10.1016/j.bodyim.2005.06.002

Bingham, J. (2012). Mattel, Inc. Please make a beautiful and bald Barbie. Retrieved July 1, 2015, from https://www.change.org/p/mattel-inc-please-make-a-beautiful-and-baldbarbie

Cash, T. F. (2011). Cognitive-behavioural perspectives on body image. In T. F. Cash \& L. Smolak (Eds.), Body image: A handbook of science, practice, and prevention (2nd edition, pp. 39-47). New York: Guilford Press.

Chamberlain, G. (2011, August 27). Disney factory faces probe into sweatshop suicide claims. Retrieved July 4, 2015, from http://www.theguardian.com/law/2011/aug/27/disney-factory-sweatshop-suicideclaims

China Labour Watch. (2012). Tragedies of globalization: The truth behind electronics sweatshops (pp. 1-136). New York, NY: China Labour Watch. Retrieved from http://digitalcommons.ilr.cornell.edu/cgi/viewcontent.cgi?article=2104\&context=glob aldocs 
Running Head: WHO STOPS THE SWEATSHOPS?

China Labour Watch. (2014). Barbie, Mickey Mouse, Optimus Prime, Thomas the Tank Engine: Who else continues to exploit toy workers? (pp. 1-67). Retrieved from http://www.chinalaborwatch.org/report/104

China Labour Watch. (2015). Mattell: Address the sweatshop conditions in your factories. Retrieved July 23, 2015, from https://www.change.org/p/bryan-stockton-address-thesweatshop-conditions-in-your-factories

Chrisler, J. C., Fung, K. T., Lopez, A. M., \& Gorman, J. A. (2013). Suffering by comparison: Twitter users' reactions to the Victoria's Secret Fashion Show. Body Image, 10(4), 648-652. http://doi.org/10.1016/j.bodyim.2013.05.001

Clifton, H. (2015, April 2). The world's most visited fashion site accused of "modern sweatshop" conditions. Retrieved July 4, 2015, from https://news.vice.com/article/asos-accused-of-modern-sweatshop-conditions-atwarehouse-in-uks-trade-union-heartland

Daly, R. (2014, May 4). 7 countries with horrific sweatshop conditions. Retrieved July 4, 2015, from http://www.therichest.com/rich-list/most-shocking/7-countries-withhorrific-sweatshop-situations/3/

Diedrichs, P. C., \& Lee, C. (2010). GI Joe or Average Joe? The impact of average-size and muscular male fashion models on men's and women's body image and advertisement effectiveness. Body Image, 7(3), 218-226. http://doi.org/10.1016/j.bodyim.2010.03.004

Do Something. (n.d.). 11 Facts about sweatshops. Retrieved from https://www.dosomething.org/us/facts/11-facts-about-sweatshops ds3375. (2014, November 4). Victoria's not so secret sweatshop labor. Retrieved from https://thegeopoliticsofbeautynyu3.wordpress.com/2014/11/04/victorias-not-so-secretsweatshop-labor/ 
Running Head: WHO STOPS THE SWEATSHOPS?

Etcoff, N. (2002). Survival of the prettiest: The science of beauty. DIANE Publishing Company.

Fraser, N. (1995). From redistribution to recognition? Dilemmas of justice in a "postsocialist" age. New Left Review, I(212). Retrieved from http://newleftreview.org/I/212/nancy-fraser-from-redistribution-to-recognitiondilemmas-of-justice-in-a-post-socialist-age

Fraser, N. (1998). Social justice in the age of identity politics: Redistribution, recognition, and participation. Culture and Economy after the Cultural Turn, 25-52.

Fraser, N. (2001). Recognition without ethics? Theory, Culture \& Society, 18(2-3), 21-42.

Hoskins, T. E. (2014). Stitched up: The anti-capitalist book of fashion. London: Pluto Press. Retrieved from http://www.history.ac.uk/reviews/printpdf/review/1788

International Labour Office. (2015). Decent work in global supply chains. International Journal of Labour Research, 7(1-2), 1-173.

Jankowski, G. S., Fawkner, H., Slater, A., \& Tiggemann, M. (2014). “Appearance potent”? Are gay men's magazines more "appearance potent" than straight men's magazines in the UK? Body Image, 11(4), 474-481. http://doi.org/10.1016/j.bodyim.2014.07.010

King, M. L. (1963). Proud to be maladjusted. Michigan, US: Western Michigan University. Retrieved from http://thepossibilitypractice.com/martin-luther-king-jr-on-creativemaladjustment/

Koskie, B. (2015). What role does the fashion industry play in women's health and self image? Retrieved July 1, 2015, from http://theconversation.tv/beauty/what-role-doesthe-fashion-industry-play-in-womens-health-and-self-image/

Lavin, M. A., \& Cash, T. F. (2001). Effects of exposure to information about appearance stereotyping and discrimination on women's body images. International Journal of 
Running Head: WHO STOPS THE SWEATSHOPS?

Eating Disorders, 29(1), 51-58. http://doi.org/10.1002/1098-

108X(200101)29:1<51::AID-EAT8>3.0.CO;2-Q

Lukács-Márton, R., Vásárhelyi, E., \& Szabó, P. (2008). Entrapped by the beauty industry:

Eating and body attitudes of those working in the beauty industry. Psychiatria Hungarica: A Magyar Pszichiátriai Társaság Tudományos Folyóirata, 23(6), 455463.

Maine, M. (2013). Body wars: Making peace with women's bodies (an activist's guide). Carlsbad, CA: Gurze Books.

Mair, A. (2014). How the fashion industry affects the bodies of young women. Retrieved April 7, 2015, from https://i-d.vice.com/en_gb/article/how-the-fashion-industryaffects-the-bodies-of-young-women

Mattera, P. (2015, June 14). Walt Disney: Corporate rap sheet. Retrieved July 4, 2015, from http://www.corp-research.org/disney

Monbiot, G. (2013, November 4). This transatlantic trade deal is a full-frontal assault on democracy. The Guardian. Retrieved from http://www.theguardian.com/commentisfree/2013/nov/04/us-trade-deal-full-frontalassault-on-democracy

Monella, L. M. (2012, April 27). Mexico: Study shows 1.5 million children work unpaid in sweatshops. Retrieved from http://www.argentinaindependent.com/currentaffairs/newsfromlatinamerica/mexicostudy-shows-1-5-million-children-work-unpaid-in-sweatshops/

Parker, I., \& Spears, R. (Eds.). (1996). Psychology and society: Radical theory and practice. London; Chicago: Pluto Press.

Parveen, S. (2014, April 23). Rana Plaza factory collapse survivors struggle one year on. Retrieved July 4, 2015, from http://www.bbc.co.uk/news/world-asia-27107860 
Running Head: WHO STOPS THE SWEATSHOPS?

Petersons, M., Phillips, E., \& Steinhaus, N. (1996). Prevalence of eating-disordered behaviors among fashion merchandising majors. Eating Disorders: The Journal of Treatment \& Prevention, 4(3), 256-263. http://doi.org/10.1080/10640269608251180

Pollin, R., Burns, J., \& Heintz, J. (2004). Global apparel production and sweatshop labour: Can raising retail prices finance living wages? Cambridge Journal of Economics, 28(2), 153-171. http://doi.org/10.1093/cje/28.2.153

Pruzinsky, T. (2004). Enhancing quality of life in medical populations: A vision for body image assessment and rehabilitation as standards of care. Body Image, 1(1), 71-81. http://doi.org/10.1016/S1740-1445(03)00010-X

Rakoska, B. (2015). Create a princess with a disability. Retrieved July 1, 2015, from https://www.change.org/p/the-walt-disney-company-create-a-princess-with-adisability

Rhode, D. L. (2009). The injustice of appearance. Stanford Law Review, 61(5), 1033-1101.

Rumsey, N., \& Harcourt, D. (2004). Body image and disfigurement: Issues and interventions. Body Image, 1(1), 83-97. http://doi.org/10.1016/S1740-1445(03)00005-6

Santonastaso, P., Mondini, S., \& Favaro, A. (2002). Are fashion models a group at risk for eating disorders and substance abuse? Psychotherapy and Psychosomatics, 71(3), 168-172. http://doi.org/10.1159/000056285

Steiner-Adair, C., Sjostrom, L., Franko, D. L., Pai, S., Tucker, R., Becker, A. E., \& Herzog, D. B. (2002). Primary prevention of risk factors for eating disorders in adolescent girls: Learning from practice. International Journal of Eating Disorders, 32(4), 401411. http://doi.org/10.1002/eat.10089

Stern, C. (2015, June 23). Plus-size model Tess Holliday shows inconsistency in clothing sizes. Retrieved July 4, 2015, from http://www.dailymail.co.uk/femail/article- 
Running Head: WHO STOPS THE SWEATSHOPS?

3136089/Plus-size-model-Tess-Holliday-slams-fashion-industry-s-inconsistent-sizinghits-criticize-body.html

Swami, V., \& Szmigielska, E. (2013). Body image concerns in professional fashion models: Are they really an at-risk group? Psychiatry Research, 207(1), 113-117. http://doi.org/10.1016/j.psychres.2012.09.009

Tasini, J. (2007, December 27). Victoria's Secret, slave labor and so-called "free trade." Retrieved from http://www.huffingtonpost.com/jonathan-tasini/victorias-secret-slavela_b_74261.html

The Fashion Mob. (2013). The fashion industry: Invest 1\% of profits to end abuse in fashion. Retrieved July 1, 2015, from https://www.change.org/p/the-fashion-industry-invest-1of-profits-to-end-abuse-in-fashion

Tiggemann, M., \& Polivy, J. (2010). Upward and downward: Social comparison processing of thin idealized media images. Psychology of Women Quarterly, 34(3), 356-364. http://doi.org/10.1111/j.1471-6402.2010.01581.x

Van Ham, L. (n.d.). Workers struggle at a Nike Factory - Kikdong in Puebla, Mexico. Retrieved June 22, 2016, from http://www.laborstandard.org/New_Postings/Kukdong_Puebla.htm

Willgress, L. (2014, March 24). Edinburgh University is first UK uni to join Electronics Watch. Retrieved July 5, 2015, from http://www.journal-online.co.uk/article/11543edinburgh_university_first_uk_uni_join_electronics_watch

Worker rights consortium. (2013). Violations of international labor standards at Arneses $Y$ Accesorios De Mexico, S.A. (pkc group): Findings, recommendations and status (pp. 1-20). Worker Rights Consortium. Retrieved from http://workersrights.org/Freports/WRC\%20Findings\%20and\%20Recommendations\% 20re\%20Arneses\%20y\%20Accesorios\%20de\%20Mexico\%2006.18.13.pdf 
Running Head: WHO STOPS THE SWEATSHOPS?

Yager, Z., Diedrichs, P. C., Ricciardelli, L. A., \& Halliwell, E. (2013). What works in secondary schools? A systematic review of classroom-based body image programs. Body Image, 10(3), 271-281. http://doi.org/10.1016/j.bodyim.2013.04.001

Ye, A. (2013, February 10). Disney sweatshops are not so fun. Retrieved July 4, 2015, from http://disneysweatshop.blogspot.co.uk/ 
Running Head: WHO STOPS THE SWEATSHOPS?

\section{Acknowledgements}

First thanks must go to Nicola Gavey whose support, advice and encouragement of this article was so invaluable. Thanks to Brendan Gough and Maxine Woolhouse for encouragement also. Many thanks are owed to Shona McCulloch and Agnes Henson whose radical perspectives have helped this paper and my thinking deeply. Final thanks go to Jim Cranshaw and People and Planet whose tireless commitment to justice work humbles me. 